\title{
Şiddeti Besleyen Bir Kategori Olarak Kimlik: Sen’in Yaklaşımı Çerçevesinde Bir Değerlendirme
}

\author{
Identity As A Category Fomenting Violence: An Evaluation Within The Framework Of Sen's \\ Approach
}

\author{
Serpil Durğun a,* \\ ${ }^{a}$ Dr. Öğr. Üyesi, Muş Alparslan Üniversitesi, Fen Edebiyat Fakültesi, Felsefe Bölümü, 49250, Muş/Türkiye. \\ ORCID: 0000-0002-7590-5600
}

\begin{tabular}{l} 
MAKALE BİLGİSİ \\
Makale Geçmişi: \\
Başvuru tarihi: 14 Haziran 2020 \\
Düzeltme tarihi: 02 Temmuz 2020 \\
Kabul tarihi: 13 Temmuz 2020 \\
\hline Anahtar Kelimeler: \\
Amartya Sen \\
Kimlik \\
Şiddet \\
Küresel Kimlik
\end{tabular}

\section{A R T I CLE INFO}

Article history:

Received 14 June 2020

Received in revised form 02 July 2020

Accepted 13 July 2020

\section{Keywords:}

Amartya Sen

Identity

Violence

Global Identity
ÖZ

Günümüz dünyasında insan, çok çeşitli ortaklıklar ve bağlantılar içerisinde var olmasına karşın, onun çoğul aidiyetleri ve çeşitli sosyal ilişkileri çatışmacı ve şiddet yanlısı siyasi liderler tarafından es geçilmektedir. Bu durum insanların katı ve dışlayıcı kategoriler halinde bölünerek tekil kimliklere indirgenmesini de beraberinde getirmektedir. Amartya Sen, insanın sadece tek bir kimliğe sahip olduğu varsayımının ya da tek bir kimliğin öne çıkarılmasının her türlü çatışma ve şiddeti beslediğini ileri sürmektedir. Bunun önüne geçmek için Sen, küresel bir kimliğin önemini savunmaktadır. Sen, günümüz dünyasında barış, güvenlik, demokrasi, adalet gibi küresel düzeydeki sorunların çözümünün ancak bu şekilde mümkün olabileceğine inanmaktadır. $\mathrm{Bu}$ kapsamda, bu makale kimliğin şiddeti nasıl beslediğinin Amartya Sen'in yaklaşımı çerçevesinden açıklanması amacına yöneliktir.

\section{Giriș}

Kimliğin oldukça tartışmalı bir kavram olduğunu söyleyen Bauman (2019: 95) bu kavramı her duyduğumuzda devam eden bir çatışma olduğundan emin olmamız gerektiğini öne sürer. En genel olarak "kimlik, bir şeyin ne olduğudur" (Gleason, 2014: 21). Apaçık gibi gözüken bu terim, esas olarak detaylıca açıklanmaya muhtaçtır. Çünkü, Antik Yunan'dan başlayıp günümüze kadar uzanan kimlik kavramına tarihsel olarak bakıldığında farklı biçimlerde karşımıza çıtığı, farklı içerimlerle dolaşıma girdiği görülmektedir. Bu noktada Brubaker ve Cooper (2014: 402) kimlik kelimesinin hem çok fazla şey ifade ettiğini hem de ziyadesiyle muğlak bir terim olduğundan hiçbir şey ifade etmediğini ileri sürerler. Kimlik muğlak ve tanımlanması zor bir terim olsa da, yine de biz Parekh'in kimlik tanımlamasını kabul edebiliriz. Kimliği "diğer tüm etmenlerin yanı sıra, bir bireyi diğerlerinden farklı kılan, onu diğerlerinden ayıran olguları ifade eden bir kavram" olarak tanımlayan Parekh (2014: 53), kimlik kavramının

\footnotetext{
* Sorumlu yazar/Corresponding author.

e-posta: s.durgun@alparslan.edu.tr
} 
kişisel ve toplumsal olmak üzere birbiriyle yakından ilişkili iki farklı boyuta sahip olduğunu ve bu iki boyutun bireyin temel kimliğini oluşturduğunu söyler:

\begin{abstract}
"Kişisel kimlik, mevcut dünyaya olan yaklaşımını ve bu dünyada bulunduğu konumu belirleyen inanış ve bağl1lıklarını ifade etmektedir. Toplumsal kimlik ise, bireyin kendini tanımlamasina ve kendisini bunun ayrılmaz bir parçası olarak görmesine vesile olan ilişkilere tekabül eder. Toplumsal kimlik doğal olarak çoğul bir kavramdır. Bir bireyin farklı kimlikleri tartması ve belli bir kısmına öncelik vermesi, kendi benlik anlayıșı ile toplumsal ve siyasi ortamı arasındaki diyalektiğin bir sonucudur" (Parekh, 2014: 53).
\end{abstract}

Hiç kuşkusuz, kimlik kavramı çağdaș politikanın kelime haznesindeki en önemli kavramdır ve Batı felsefesinde Antik Yunan'dan başlayıp çağdaş analitik felsefeye kadar uzanan bir tarihe sahiptir (Brubaker\&Cooper, 2014: 403404). Bu kapsamda Maalouf (2019: 15) kimlik kavramının Sokrates'in 'Kendini tanı!'sından başladığını söyler. Nitekim, Platon'un Alkibiades diyaloğunda Sokrates, Delphi tapınağında yazan 'kendini bil!' yazısının düsturunda Alkibiades'e ruhtaki gerçeği keşfettirmeye çalışır. Platon'a (1962: 13) göre, kendimizi bilmezsek kendimizi daha iyi kılamayı. Bedenimize dair bir bilgi, insanın kendisini bilmesi anlamına gelmez, kendini bilmek ruhumuzu bilmektir (1962: 17). Bu noktada Foucault (1999: 39), Antikçağda 'kendini bilmek' ilkesinin yaşamla ilgili soyut bir ilke olmadığını belirtir. Diyalogda Alkibiades diyalektik bir seyir içinde ben'i bulmaya çalışır ve aynı zamanda bu süreçte kendine özen kavramı da tahlil edilir. Bu tahlil, 'kişinin özen göstermesi gereken benlik nedir' ve 'bu özen neleri içerir' olmak üzere iki soruya dayanır. Bu sorulardan ilki olan 'ben ya da benlik nedir?' sorusunun cevab1, dönüşlü bir zamir olan ben'in barındırdı $\breve{g}_{1}$ iki anlamda bulunur: Ben hem auto, yani 'aynı' demektir hem de kimlik kavramını ifade eder. Ben'in bu ikinci anlamı -kimlik- soruyu 'benlik nedir?' den 'kimliğimi bulacağım yer neresidir?' şekline dönüştürür (1999: 48).

Giyim, kuşam, araçlar ya da mülkler benlik değildir. Benlik bedenin ilkesinde değil, ruhun ilkesinde bulunduğundan özen gösterilecek olan beden değil, ruhun kendisidir. Burada özen, etkinliğe yöneliktir, yani töz olarak ruha yönelik bir özen değil, ben'e yönelik bir özen (öz-özen) söz konusudur (Foucault, 1999: 48).

$\mathrm{Bu}$ özenin neler içerdiğine dair diğer soruya yöneldiğimizde ise, kişinin özenin nelerden oluştuğunu bilmesi için ruhun nelerden oluştuğunu bilmesi gerekir (Foucault, 1999: 48). Kendinin ne olduğunu bilmek, bilge olmaktır. Buradan hareketle, ruh kendini bilmek isterse bir ruha ve özellikle ruhun erdeminin/bilgeliğin bulunduğu yere bakmalıdır, zira ruhta bilgeliğin bulunduğu yer tanrısaldır (Platon, 1962: 19). Ruhun, doğru davranış ve siyasal eylemin temeli olarak hizmet edecek kuralları keşfedebilmesi tanrısal tefekkürle mümkündür. Doğru siyasal eylemin dayanacağı ilke, burada ruhun kendini tanıma çabası olarak belirir (Foucault, 1999: 48). "Alkibiades'te ruh kendisiyle bir ayna ilişkisi içindedir, bu ilişki hafıza kavramıyla bağlantılıdır ve diyalog ruhtaki gerçeği keşfetme yöntemi olarak kabul görür" (1999: 58).

Yukarıda bahsedildiği gibi, kimlik kavramı Sokrates'in 'Kendini tanı!'sından başlamakla birlikte, söz konusu kavram İngilizcede 16. yüzyıldan itibaren kullanılmaya başlanmıştır. Latince idem (aynı) kökünden gelen kimlik, felsefede John Locke'dan bu yana zihin-beden sorunuyla ilişkili olmuştur. Tanımlanması zor bir terim olan kimliğin, sosyal bilimlerde yaygın bir terim olarak kullanılması ise, ancak 1950'lerde gerçekleşmiştir (Gleason, 2014: 22-23). Kimliğin 1950'lerde popülerlik kazanması, sosyal bilimlerin insanlık durumunun sırlarını çözebileceğine yönelik duyulan inançla yakından ilgilidir. Söz konusu kavram, İkinci Dünya Savaşı'ndan sonra Amerikan toplumunda karşılaşılan sorunlar nedeniyle, birey ve toplum arasındaki ilişkiye odaklanıp ulusal karakter çalışmalarına yönelik olarak dolaşıma sokulmuştur. Özellikle Erik Erikson'un çalışmalarıyla popülerlik kazanan kimlik (Gleason, 2014: 41-43) kavramının yayılması, esas olarak sembolik etkileşimcilerin çalışmalarıyla mümkün olmuştur (Brubaker ve Cooper, 2014: 405).

Tarihsel olarak bakıldığında, 1950'lerde bireyin toplumla ilişkisi sorunu köksüzlük ya da kimlik arayışıyla ilişkili olarak ele alınırken, 1960'larda söz konusu sorun, 'kimlik krizi' şeklinde yeni bir biçimle karşımıza çıkmıştır. 1970'ler ise, kimlik kavramıla etnisite arasındaki bağlantıların öne çıktığı bir dönem olarak belirir (Gleason, 2014: 48-50).

1980'lerden itibaren ise, kimlik sohbetlerinin akademinin hem içinde hem de dışında büyümeye başladığını ve bugün de büyümeye devam ettiğini belirten Brubaker ve Cooper (2014: 407-408), toplumsal cinsiyet, 1rk ve sinif kavramlarının 1980'lerde yükselişe geçmesiyle birlikte toplumsal cinsiyet, cinsellik, 1rk, din, etnisite, göç, milliyetçilik, yeni toplumsal hareketler, kültür ve kimlik siyaseti üstüne yapılan çalışmalarda kimliğe yoğun bir ilginin olduğunu söyler. Bunun yanı sıra, kimliğin inşa edilmiş, akışkan ve çoklu olarak taahhüt edilmesinin, kimliğe ilişkin hâkim konstrüktivist tavrı oluşturduğuna dikkat çeken Brubaker ve Cooper (2014: 403), tam da bu noktada "kimlik eğer çokluysa, salt kategorileri, üniter ve dışlayıcı gruplara dönüştürmeye çalışan politikacıların ulaşmaya çalıştığ1 -kimi zaman da ulaştığ1- korkunç tekilliği nasıl anlamamız gerektiği” sorusunu sorar.

Bu kapsamda çalışma, Amartya Sen'in perspektifinden, yukarıdaki sorunun cevabını anlama amacına yöneliktir. Düşünce ve eylemlerimizin kimlik kavramının çok yönlü etkisi altında olduğunu vurgulayan Sen (2010: 12), günümüz dünyasında karşılaşılan politik ve sosyal çoğu meselenin farklı grupları ilgilendiren, birbiriyle bağdaşmaz kimliklerin çatışan iddiaları etrafında döndüğünü söyler. Küresel çatışma politikalarına çoğunlukla, dünyadaki dinsel ve kültürel bölünmelerin sonucu gözüyle bakıldığına dikkat çeken Sen, dünyanın gitgide bir dinler ve uygarlıklar federasyonu olarak görüldüğünün ve böylece insanların kendilerini algılamasının diğer biçimlerinin görmezden gelindiğinin altını çizer. Dünya nüfusunun uygarlıklar ya da dinler arasında bölünmesinin, insan kimliği konusunda içe kapanmacı bir yaklaşıma yol açtığını düşünen Sen, insanları yalnızca tek bir grubun mensubu olarak gören bu yaklaşımın her türlü çatışma ve şiddeti beslediğini öne sürer.

\section{2. Şiddeti Besleyen Bir Kategori Olarak Kimlik}

1980’lerin sonunda Birleşmiş Milletler Kalkınma Programı çerçevesinde örgütlenen kapasite yaklaşımının temellerini 
Martha Nussbaum ile birlikte atan ve 1999 yılında insani kalkınma yaklaşımını geliştirerek kapasite yaklaşımı/insan yeterlilikleri yaklaşımı olarak ortaya koyan (Tilak, 2002) Hintli ekonomi ve felsefe profesörü Amartya Sen, insanı çok çeşitli gruplara mensup olan, çoğul aidiyetlerden, çok sayıdaki kimliklerden oluşan karmaşık ve grift sosyal bir varlık olarak görür. Buna karşın, insana ilişkin bu gerçeğin günümüz dünyasında göz ardı edildiğini, insanın sadece tek bir kimliğinin öne çıkarılıp bunun kutsandığını düşünür (Sen, 2010).

$\mathrm{Bu}$ düşüncelerini Kimlik ve Şiddet adlı çalışmasında açımlayan Sen (2009: 334), kimlik siyasetinin doğasının ve dinamiğinin anlaşılması amacıyla kaleme aldığı söz konusu çalışmasında, insanların sahip olduğu çoğul aidiyetlerin tanınması çağrısında bulunur.

Sen'in (2010: 198) bu çağrısı çok çeşitli kategorilerin, çoğul aidiyetlerin kimlik denilen şeyi oluşturmasına karşın, tek bir kategoriye odaklanıldığını, tek bir aidiyetin öne çıkarıldığını ve böylece çatışma ya da şiddeti besleyen, kışkırtan kutuplaşmış bir vizyonun günümüz dünyasına yayılmış olduğunu düşünmesinden kaynaklanır.

$\mathrm{Bu}$ düşünce doğrultuda Sen, kimlik denilen şeyi çok çeşitli kategoriler, çoğul aidiyetler oluşturduğu halde, kişinin sahip olduğu çok sayıdaki kimliklerden sadece birini öne çıkartarak kişiyi görmenin, onu tanımlamanın nasıl mümkün olduğu sorusuna odaklanır ve şiddet amacına hizmet eden tekil bir kimlik savunuculuğunun işleme sürecini aşağıdaki gibi ifade eder:

Kendine özgü bir kimlik savunuculuğunu şiddet amaciyla yapmak, bir kimlik grubunu -gündemdeki şiddet amacıyla doğrudan bağlantılı olarak - özel bir odaklanmayla diğerlerinden koparma biçimini alır ve ondan hareketle, seçmeci bir vurgulama ve kışkırtmayla, diğer ortaklık ve aidiyetlerin geçerliliğini gölgede bırakır (Sen, 2010: 198).

Burada Sen (2010: 198), şiddeti besleyen ya da tırmandıran bir şekilde tekil bir kimliğin öne çıkarılmasını bir tür savaş sanatı olarak görür. Bu savaş sanatı düşünme özgürlüğünü, sağduyuyu ve yatıştırıcı aklı safdışı etmek için hem bazı temel içgüdüleri hem de parçasal bir mantık tarzını kullanır. $\mathrm{Bu}$ noktada belirli bir eylem amacıyla, kişinin sahip olduğu çok sayıdaki kimliklerden sadece biri çekilip öne çıkarılır. Sözgelimi, "bir Sırp bir Arnavut değildir ya da âri bir Alman kesinlikle âri bir Almandır" (2010: 199) gibi kişinin diğer aidiyetlerinin görmezden gelinmesini sağlayacak tek bir kimlik olarak kişi sunulur. Hemen ardından, savaşçı bir biçimde bu tek kimliğin gerekleri kavramsal bir kafa karışıklığına yol açacak bir biçimde yeniden tanımlanır (2010: 199).

Bir grup insanla kurulan özdeşlik duygusunun, uygun bir kışkırtmayla, başka bir gruba gaddarca davranmanın güçlü bir silahı haline getirilebileceğini söyleyen Sen, dünyada görülen çatışma ve şiddetin çoğunun seçeneksiz bir kimlik yanılsaması sayesinde sürdürüldüğünü belirtir. İnsanın diğer aidiyetlerini yok eden egemen bir kimliğin harekete geçirilmesiyle ve akabinde buna uygun bir savaşçı kimliğin oluşturulmasıyla, yerel ya da küresel şiddet ve terörizm arasında çok yakın bir ilişki olduğunu düşünür. Sen, belirli bir kimliğin öne çıkarılmasını şiddet yanlıları ya da kışkırtıcıları tarafından uygulanan nefret tohumları ekme sanatı olarak adlandırır ve bunun diğer insanlara karşı beslediğimiz sempati duygusunu ve doğal iyilikseverliği ne yazık ki bastırdığını öne sürer (Sen, 2010: 15).
Şiddetin, genellikle bölücülükten yararlanan siyasi gruplar tarafından beslendiğine dikkat çeken Sen (2009: 353), insanları katı kategoriler halinde bölmenin, yanılsama grupları yaratmakla kalmayıp aynı zamanda bu gruplar arasındaki anlaşmazlıkları kışkırtmak amacıyla da kolaylıkla kullanılmaya açık olduğunu vurgular (Sen, 2010: 201). İnsanlardan nefret etmenin esas olarak kolay bir şey olmadığına inanan Sen (2010: 197-198) insanlar arasında nefret tohumları ekilmesini yönlendiren kişi ya da kesimlerin var olduğunu belirtir. Sen'e göre, söz konusu kesimler şiddet amacına hizmet eden tekil bir kimlik yanılsaması yaratmakta ve bu kimlik yanılsaması işkence ve katliam komutanları tarafından ince bir şekilde hem beslenmekte hem de kışkırtılmaktadır.

Bunun yanı sıra Sen (2010: 199), insanların sahip olduğu çok sayıdaki kimliklerden sadece tek bir kimliğin öne çıkarılmasını ya da insanların tekil kimlik kutucuklarının içine hapsedilmesini, uygarlık tasnifçilerinin, kültür ve uygarlık teorilerinin çoğunun sahip olduğu özelliklerden biri olarak görür. Söz konusu teoriler şiddet savunuculuğu yapmamakla birlikte, insanların sahip olduğu çoğul kimlikleri ya da çok çeşitli aidiyetleri es geçerek onları tek bir özel sosyal grubun mensubu olarak ele aldığından içe kapanmacı bir özelliğe sahiptir. Bu özelliğe sahip olan teoriler, uygarlıkları birbirinden ayırmakta ya da belirli bir topluluk içine hapsetmektedir. Sözgelimi, Hindistan'1 'Hindu Uygarlı̆̆ı' kutucuğuna yerleştiren uygarlık tasnifçileri, Hindistan'da Müslümanların, Hintli Sihlerin, Jainlerin, Parsilerin ve Hristiyanların bulunduğunu dikkate almayarak ve Hindistan'da yaşayan insanlar arasındaki iç bağlantıların sadece din aracılığıyla gerçekleştiğini varsayarak politik, ekonomik, sosyal, ticari, sanatsal, müzik ve diğer kültürel uğraşlara katılım yoluyla bir arada yaşayan insanlar arasındaki yaygın iç bağlantıları görmezden gelmektedir.

İçe kapanmacı teorilerin sahipleri kendi teorilerini her ne kadar bir çatışmanın yaratıcısı olarak değil, keşfedicisi olarak görseler de teori pratiği etkilemektedir. Zira, her türlü politik ve ekonomik faaliyet, sosyal düşünce, kamu politikaları teorilerin ciddi bir biçimde etkisi altındadır. Söz konusu teorilerin uygarlıkları, insanları yapay bir biçimde tekil kimliklere indirgemesi hem kavramsal bir kafa karışıklığı yaratmakta hem de çatışmacı ve şiddet yanlısı liderler tarafindan sekter dışlayıcılığı pekiştirme amacıyla kullanılmaktadır (Sen, 2010: 201).

İnsanları içinde yaşadığı toplumla birlikte ya da sosyal bağlam içinde ele alan toplulukçu sosyal teorilerin insanları daha eksiksiz ve daha sosyal açıdan görme çabası, gerçek yaşama uygulandığında, insanları katı bir şekilde kategorilendirerek onları tek bir grubun mensubu olarak görmek şeklinde oldukça sınırlı bir kavrayışa takılı kalmıştır. İnsan denilen varlık çok çeşitli ortaklıklar ve bağlantılar içerisinde var olmasına karşın, insanın sosyal durumunun çoğul özelliklerinin zenginliği azımsanmış ve böylece insanın çoğul aidiyetleri, çok çeşitli sosyal ilişkileri görmezden gelinerek insan varlığının zenginliği eksiltilmiştir (Sen, 2010: 200).

Ayrıca, Sen'e (2010: 202) göre, herhangi bir dinin seçkinliğine ilişkin teoriler de insanların sadece dinsel aidiyetlerini ön plana çıkararak diğer aidiyetlerinin geçerliliğinin görmezden gelinmesine yol açmakta ve böylece dinsel çatışma ve şiddetin kavramsal temelini 
oluşturmaktadır. Sen'in bu düşüncesi, dine yer olmayan bir dünyanın hayalini kurduğu şeklinde anlaşılmamalıdır, zira din olmadan dünyayı düşünemeyeceğini söyleyen Maalouf (2019: 81-82) gibi o da, maneviyat ihtiyacının aidiyet ihtiyacından ayrılması gerektiğine vurgu yapmaktadır. Bu bağlamda Maalouf, dinin savaş halindeki budunlara çimento rolünü üstlenmemesi için, fanatizmi, terör ve savaşı beslememesi için dinselin bir kimlik bildirimi olmaktan çıkarılması gerektiğini düşünür. Dini ve etnik kimlik arasında bir benzerlik olduğunu öne süren Smith (1994: 23) ise, hem dini hem de etnik kimliğin benzer bir kültürel sınıflama ölçütünden geldiğini belirtir. Smith, çoğu zaman her iki kimliğin çakıştığını ve birbirlerini güçlendirdiğini, tek tek ya da birlikte güçlü cemaatleri besleyip harekete geçirdiğini öne sürer.

Sen (2009: 353) için, dini kimliğe saygı duyulması hiç şüphesiz çok önemlidir; bununla birlikte dini kimlik insanların sahip olduğu kimliklerden sadece bir tanesidir. İnsanların sadece dinsel bir kimliğe sahip olmadığını, dinsel kimliğin yanı sıra çok sayıda ve çok çeşitli kimliklere de sahip olduğuna dikkat çeken Sen, bir ülkenin öncelikle bir dine mensup topluluğun toplamı olarak değil, vatandaşlarının toplamı olarak görülmesi gerektiğini belirtir (2010: 203-204). Zira, bir ülkede yaşayan vatandaşlar arasında yaygın iç bağlantılar sosyal, politik, ekonomik, ticari, sanat, müzik gibi pek çok kültürel uğraşlara katılımla, çok çeşitli aidiyetlere katılım yoluyla oluşmaktadır (2010: 200).

Bu noktada Sen (2010: 12) dünya nüfusunun daha önceleri uluslara ve sınıflara dayanarak bölündüğünü, şimdi ise din ya da uygarlık tarafindan tanımlanan tek bir grubun mensubu olarak görüldüğünü söyler. Bilindiği gibi, modern ulus devletin doğuşundan itibaren Avrupa ulusları Romantizmden yoğun şekilde etkilenerek, ulus olmanın kökeninde kanı, toprağ ulusal bir kimliğin zorunlu veya en azından merkezi öğeleri olarak görmüşlerdir (Nussbaum, 2018b: 32). Ulusal kimliğin bu zorunlu, merkezi öğelerinin ya da sınıf, cins, 1rk, din gibi kolektif kimlik türlerinin millî kimlikle örtüşebileceğini veya terkibe girebileceğini belirten Smith (1994: 221), kolektif ebediyet ve itibar ihtiyac1, etno-tarihin gücü, yeni sınıf yapılarının rolü ve modern dünyada devletler-arası sistemin sahip olduğu tahakküm gibi nedenlerden ötürü, milli kimliğin diğer kollektif kültürel kimliklerden daha tesirli ve kalıcı bir etkiye sahip olduğunu savunur (Smith, 1994: 270). Benzer şekilde Bauman (2019: 32) da, ulusal kimliğin 'biz' ve 'onlar' arasında sınır çizmek için tekelci bir hakkı amaç edinen devlet tarafindan titizlikle inşa edildiğinden dolayı ulusal kimliğin hiçbir zaman diğer kimlikler gibi olmadığını, kesin ittifak ve özel sadakat talep etmeyen diğer kimliklerin aksine, ulusal kimlikle bir muhalefet ve rekabet içine girilemeyeceğini belirtir. Bauman'a (2019: 48) göre, uyruk statüsü kimliklerin en geneli ve en kapsayıcısı olup kendisi dışındaki diğer kimliklere anlam vererek onları ikincil ve bağımlı statüye indirgeyen bir supra-kimlik durumundadır. Nitekim, yirminci yüzyılın özellikle ilk yirmi yılında toplumsal sınıfların Marksist analizinin ön plana çıkmasıyla birlikte, sınıf bütünleştirici bir kimlik türü olarak sivrilse de ulus inşası döneminde uyruğa atfedilen 'meta kimlik' statüsüne sahip olamamıștır. 1980'lerde sınıfın bambaşka ve ayrintılı taleplere cevap veremez hale gelmesiyle birlikte toplumsal cinsiyet, 1rk ve ortak kolonyal geçmiş gibi çeşitli kolektif kimlik türleri sınıfın bütünleștirici gücüne öykünmüşlerdir (2019: 48). Bu bağlamda, diğer kolektif kimlik türlerinin milli kimliğin yönünü etkileyebilseler de, altını oymakta nadiren başarıya ulaştıklarını söyleyen Smith (1994: 221), dünyanın her köşesinde millî kimliğin gücünü sebatla devam ettirdiğini öne sürer. Ancak bu noktada Smith - millî kimliğin gücünü sebatla devam ettirmesinde hem bir umut hem de bir tehlike görür (1994: 270). Smith'e (1994: 271) göre, milli kimlik popüler rızaya sahip ve popüler bir coşku sağlayan siyasî dayanıșmanın yegâne tahayyülünü ve rasyonelini verir. Diğer bütün tahayyüller, bütün rasyoneller milli kimlikle karşılaştırıldığında soluk ve bulanık kalır. Zira, milli kimliğin dışındaki diğer tahayyüller bir seçilmişlik duygusu sunmazlar, biricik nitelikte bir tarihleri ve özel kaderleri de yoktur. Smith, iște bu vaadleri ancak milliyetçiliğin yerine getirildiğini öne sürer ve insanların kendisini milletle özdeşleştirmeyi sürdürmesinin gerçek nedeni olarak bunu görür. $\mathrm{Bu}$ bakımdan Smith milliyetçiliğin önümüzdeki yüzyılda da insanlığa temel kültürel ve siyasî kimliklerini sağlamayı sürdüreceğini ileri sürer (Smith, 1994: 271). Ancak, küreselleşme olgusu Smith'in bu öngörüsünü gölgelemiştir. Zira Bauman'ın (2019: 39) da belirttiği gibi, küreselleşme ile birlikte devletin ulus ile olan sağlam ve dayanıklı evliliği çözülmüş veya devletin ulus üzerindeki nüfuzu artık ortadan kalkmıştır. Dolayısıyla ulus devletlerin yurttaş kimliği, günümüzde yerini bireysel kimliklere bırakmıştır (Koyuncu ve Günerigök, 2019: 139).

Son olarak, Smith (1994: 270) milli kimliklerin içinde, etnik çatışmaların her yere yayılması ve kızışması, daha büyük bir millî türdeşlik hamlesi esnasında sindirilemeyen azınlıklara zulmün reva görülmesi, terörün, etnik kırımın ve soykırımın haklı gösterilmesi gibi tehlikeler de barındığını söyler. Bu bağlamda Bauman (2019: 31) milli ya da ulusal kimliğin en başından itibaren agonistik -kavgac1- bir nosyon ve bir savaş narası niteliğinde olduğunu ve uzun süre de öyle kaldığını öne sürer.

$\mathrm{Bu}$ tür tehlikeleri sadece milli kimliğin barındırmadığını aynı zamanda din ya da uygarlık tarafindan tanımlanan kimliklerde de aynı tehlikenin söz konusu olduğunu düşünen Sen, insanların din ya da kültür temelinde kendilerine özgü kategorilere ayrılabileceği varsayımını, günümüz dünyasında çatışma potansiyelinin temel kaynaklarından biri olarak görür. İçinde bulunduğumuz çağda dünya bir dinler ya da uygarlıklar/kültürler toplamı sayıldığından insanların cinsiyet, dil, sınıf, meslek, bilim, ahlâk ve politik tercihlerinden oluşan diğer kimlikleri es geçilmektedir (Sen, 2010: 15-16). Sen'e (2010: 16) göre, din ve uygarlık temeline dayalı bu bölücülük ya da indirgeme, şiddet ve çatışmaya çok büyük katkılarda bulunmaktadır. Benzer şekilde Maalouf (2019: 75) da, günümüzde dinsel aidiyetin vurgulanmasının, onu kimliğin ana öğesi olarak görmenin, elli yıl öncesine nazaran daha yaygın bir tavır olduğunu söyler. İnsanların dinsel, etnik, ulusal ya da başka kimlikleri adına cinayetler işlemesinin temelinde Maalouf (2019: 15), insan kimliği içinden tek bir öğenin, diğerlerinin zararına olacak bir şekilde yüceltilmesini ya da bütün bir kimliğin öfkeyle ilan edilen tek bir aidiyete indirgenmesini görür ve katillerin bu şekilde imal edildiğini öne sürer (2019: 12). Kimlik tek bir aidiyete indirgendiğinde, insanları katı, hoşgörüsüz, taraf tutucu ve baskıcı bir şekilde katillere ya da katillerin yandaşlarına dönüştürdüğünü savunan Maalouf (2019: 30), kimliğin tek 
bir aidiyete indirgenmesini ölümcül kimlikler olarak adlandırır. Ölümcül kimliklerin ortaya çıkmaması için Maalouf (2019: 21-22), insan kimliğinin bileşenleri çok sayıda olduğundan kimliğimizin ve aidiyetlerimizin çoğul olduğunun ve her insanla birtakım ortak aidiyetlerimiz bulunduğunun anlaşılmasını ve insanların çoğul kimliklerini benimseme konusunda yüreklendirilmelerini ister.

Kimliğe ilişkin indirgeme, kötü niyet ve kavram kargaşasını günümüz dünyasında karşılaşılan çatışma ve şiddetten büyük ölçüde sorumlu gören Sen (2010: 14), şiddet kışkırtıcılarının tek bir kimliği öne çıkartarak dışlamalar ve dayatmalar yoluyla şiddeti beslediklerini belirtir. Bunun yanı sıra, kişinin sadece tek bir kimliğe sahip olduğunun varsayılmamasın ya da tek bir kimliğin öne çıkarılmamasın şiddetin doğal ya da hoşgörüyle karşılanmasına neden olan bir atmosferin oluşmasını da beraberinde getirdiğini vurgular (Sen, 2010: 205). Bu noktada Sen, çok sayıda ve birbirinden çok farklı aidiyetlerimiz olduğunun açıkça görülüp savunulmasıyla her türlü keskin ve dışlayıcı perspektiften sırrlabileceğimizi ve böylece şiddet kışkırtıcılarının oyununu bozabileceğimizi düşünür. $\mathrm{Bu}$ düşünce esas olarak "eşit ve adil bir dünyanın gerçekleşmesi için nasıl bir sorumluluk almamız gerektiği üzerine düşünmeyi bırakmamamız" (Nussbaum, 2018a: 134) gerektiğine dairdir. Her insanın içinde yaşadığı dünyanın değişmesinden ve gelişmesinden bizzat sorumlu gören Sen (2004: 381), daha barışçıl ve daha adil bir dünyanın oluşumu için çaba göstermemizi ister. Onun bu düşüncesinin, Parekh'in (2014: 55) kimliğin kişisel ve toplumsal boyutunun yanında, bir üçüncü boyut olarak belirlediği "kişinin insan olma farkındalığına, nasıl davranması ve yaşaması gerektiğini sorgulamasına dair" olan kimliğin üçüncü boyutuyla yakından ilişkili olduğu söylenebilir. Zira Sen (2009: 142), belirli bir ulusun, dinin, etnik kökenin mensubu olsak da insan toplumuna ait olma ya da insan olma kimliğinin, hepimizin en temel kimliği olduğuna inanır.

Belli bir şekilde parçalara ayrılmış olan bir dünyanın, dünyayı biçimlendiren çoğul ve çeşitliliğe sahip kategoriler evrenine kıyasla çok daha kolay bölünebilir bir dünya olduğuna dikkat çeken Sen (2010: 14), insanların bir arada barış ve uyum içinde yaşamasını, insan kimliğinin çoğulluğuna ilişkin bir anlayışa sahip olmaya dayandırır. Günümüz dünyasında barış umudunu, insanların tekil kimlik kutucuklarının içine tıkılmamasına, minyatürleştirilmemesine ve dolayısıyla insan aidiyetlerinin çoğulluğunun ve her birinin değerliliğinin kabul edilmesine bağlar (2010: 16-17).

Benzer şekilde Maalouf (2019: 129) da, insan kimliğini bir dışlanma aracı ve bazen de savaş aleti haline getirilmiş tek bir aidiyetle eritmek yerine, kimliğin çok çeşitli aidiyetlerin toplamı olarak algılanmasına insanların teşvik edilmesini ister. Her insanın hem yaşadığı ülkeyle hem de dünyayla kendisini özdeşleştirebilmeyi sağlayacak birtakım davranış ve alışkanlıklar kazanabileceğine inanan Maalouf, 'ölümcül kimlikler' çağının aşılmasını arzular. Bu noktada, ayrışma yerine bütünleşmeye odaklanarak her insanın kimliğini farklı kültürlere samimi ve komplekslerden arınmış bir şekilde açarak kimliklerin uzlaştırılmasını talep eder. Aksi takdirde, Maalouf insanlığın yolunu kaybetmiş kan dökücü çılgınlardan oluşan ordular kurmasını kaçınılmaz olarak görür (2019: 33).
Dünyanın hiçbir özel ırka, hiçbir özel ulusa ait olmadığını vurgulayan Maalouf (2019: 103) gibi Sen (2010: 204) de, dünyanın küresel mirasında tüm uygarlıkların, tüm kültürlerin payı olduğunun altını çizer. Sen, insanlığın geçmişinin daha doğru ve daha eksiksiz kavranmasını, Batı uygarlığının diğer uygarlıklara üstünlüğüne ilişkin yanlış kabulün aşılmasına bağlar. Zira Sen, insanlığın bugün geldiği noktayı, her türlü başarı ve kazanımı dünyadaki gelmiş geçmiş tüm uygarlıkların katkılarının bir sonucu olarak görür. Sen'e göre, bu gerçeği göz ardı eden kültür ve uygarlık teorileri bilim, sanat, felsefe gibi insanlığa ait tüm başarı ve kazanımları sadece Batı uygarlığına mal ederek, insanlığın entelektüel ufkunu sınırlamanın yanı sıra Batılı ve Batılı olmayan şeklinde bir karşıt kutuplaşmaya da neden olmaktadırlar. Sen için, çatışma ve şiddet duygularını beslemekten başka bir işe yaramayan bu kutuplaşma ya da cepheleşme, insanlığı eksilten ve kimlik çatışmalarını besleyen yapay bir ayrımdır (2010: 206).

Sen'e göre günümüz dünyasında küresel adalet, küresel demokrasi elzem bir gereklilik durumundadır. $\mathrm{Bu}$ gereklilik, küresel bir kimlik düşüncesinin insanlara kazandırılması ve yaygınlaştırılması gerekliliğini de beraberinde getirmektedir. Daha adil ve daha barışçıl bir dünyanın oluşumunda küresel bir kimlik düşüncesinin önemini savunan Sen, aynı Maalouf (2019: 85) gibi, küreselleşen dünyada ortak kaderimizin bilincine vararak kimlik kavramına ilişkin yeni bir bakış açısına ihtiyaç olduğunu savunur. Bu bağlamda Maalouf (2019: 85) insan kimliğine ilişkin, insanın bütün aidiyetlerinin toplamı gibi algılanacak ve içinde insanlık toplumuna aidiyetin gitgide daha fazla önem kazandığı, özel aidiyetlerimizi de silmeden, sonunda bir gün esas aidiyet haline gelecek hümanist bir ufkun taşıyıcısı olan çok daha geniş bir aidiyet anlayışının yerleşmesini arzular (2019: 82). Sen'in savunduğu küresel kimlik düşüncesinin, Maalouf'un özlemini duyduğu gezegensel aidiyet ya da "gezegen kabilesine" aidiyet düşüncesiyle koşut olduğu söylenebilir.

Küresel kimliği, küresel aidiyet duygusunu, içe kapanmacı olmayan bir kimlik anlayışının yerleştirilmesiyle mümkün gören Sen, içe kapanmacı olmayan kimlik anlayışının, kişilerin sahip oldukları yerel ya da ulusal kimliklerle yan yana var olabileceğini düşünür (2010: 208). Çünkü Sen için, insan kimliğine ilişkin içe kapanmacı olmayan bir anlayışın yerleşmesi, ulusal yükümlülüklerimizin ve yerel bağlılıklarımızın küresel bir aidiyet duygusuyla baştan aşağı yer değiştirmesi anlamına gelmemektedir. Sen'e göre, küresel kimlik, bizim diğer kimliklerimizi, aidiyetlerimizi yok etmeden de payına düşeni alabilir ve almalıdır (Durğun, 2013: 118). İnsanların ulusal ya da yerel bağlılıkları küresel aidiyet duygusu ile bir çatışma durumunda olmak zorunda değildir. Küresel kimlik, yerel ya da ulusal kimliğe bir tehdit de oluşturmaz (2010: 205). Küresel kimlik, ulusal kimliğe bir tehdit oluşturmak bir yana, daha güvenli bir dünya olanağına kap1 aralar. Günümüz dünyasında küresel kimlik düşüncesi birbirinden farklı insan ve ulusları birbirine bağlayan ortak bir kimlik olarak, insan varlığının minyatürleştirilmesine, çatışma ve şiddeti doğallaştırıp hoşgörüyle görülmesine karşı durmaya tüm insanları çağırır (2010: 208). Bu çağrı, tüm insanların ortak değerler, etik ve küresel aidiyet duygusunun çatısı altında birleşmelerine ve böylece yakın gelecekte bir uygarlıklar savaşının ortaya çıkma ihtimalinin önünü kesmeye yöneliktir. Sen'in bu çağrısı oldukça manidardır. 
Zira, Bauman'ın (2019: 107-108) da vurguladığı gibi, herkesin birbirine karşılıklı olarak bağımlı olduğu, herkesin ortak güvenliğini sağlama almak istediği bu küreselleşen dünyada, "ya birlikte yüzeriz ya da birlikte batarız."

\section{Sonuç}

İnsan olmanın, insanın sahip olduğu çok çeşitli kimliklerle yakından ilişkili olduğunu düşünen Sen (2002), insanı çoğul aidiyetlerden, çok sayıdaki kimliklerden oluşan karmaşık ve grift sosyal bir varlık olarak görür. Sen'e göre, günümüz dünyasında insan çok çeşitli ortaklıklar ve bağlantılar içerisinde var olmasına karşın, insanın çoğul aidiyetleri, çeşitli sosyal ilişkileri es geçilmektedir. Bu durum insanların katı ve dışlayıcı kategoriler halinde bölünerek tekil kimliklere indirgenmesini de beraberinde getirmektedir. Böyle bir indirgemeye Sen'in perspektifinden bakıldığında, insanın sadece tek bir kimliğe sahip olduğunun varsayılması ya da tek bir kimliğin öne çıkarılması içe kapanmacı bir yanılsamanın getirisi olarak her türlü çatışma ve şiddeti beslemektedir. Sen, tek bir kimliğe vurgu yapılıp insanların yapay bir şekilde katı ve dışlayıcı kategoriler halinde bölünmesinin hem yanılsama grupları yaratacağını hem de bu gruplar arasındaki anlaşmazlıkları kışkırtmak amacıyla kolaylıkla kullanılacağını düşünür. İnsana ilişkin tek bir kimlik öne çıkarıldı ̆̆ 1 takdirde, insanlar arasında nefret tohumlarının ekilmesine ve şiddetin doğal görülüp hoşgörüyle karşılanmasına neden olan bir atmosferin oluşacağını öne sürer. İnsanların sahip olduğu çok sayıdaki kimliklerden sadece tek bir kimliğin öne çıkarılmasını ya da insanların tekil kimlik kutucuklarının içine hapsedilmesini kültür ve uygarlık teorilerinin, uygarlık tasnifçilerinin çoğunun sahip olduğu özelliklerden biri olarak gören Sen, bu teorileri içe kapanmacı teoriler olarak adlandırır. İçe kapanmacı teoriler şiddet savunuculuğu yapmamakla birlikte insanları, uygarlıkları birbirinden ayırmakta, belirli bir topluluk içine hapsetmekte, onları yapay bir şekilde tekil kimliklere indirgeyerek minyatürleştirmektedir. Daha da önemlisi, sosyal düşünceyi, politik ve ekonomik faaliyeti, kamu politikalarını, diğer bir ifadeyle her türlü pratiği etkileyen bu teoriler, kavramsal bir kafa karışıklığı yaratmasının yanı sıra çatışmacı ve şiddet yanlısı liderler tarafindan sekter dışlayıcılığı pekiştirme amacıyla da kullanılmaktadır.

$\mathrm{Bu}$ noktada Sen, çok sayıda ve birbirinden çok farklı aidiyetlerimiz olduğunun açıkça görülüp savunulmasıyla her türlü keskin ve dişlayıcı perspektiften sıyrılabileceğimizi ve böylece şiddet kışkırtıcılarının oyununu bozabileceğimizi düşünür. Günümüz dünyasında barış, güvenlik, demokrasi, adalet gibi küresel düzeydeki sorunsalların çözümüne acil bir şekilde ihtiyaç duyulduğunu vurgulayan Sen, söz konusu sorunsalların çözümüne yönelik olarak küresel bir kimlik düşüncesinin önemini savunur. Küresel kimliğin, insanlar ve uluslar arasında içe kapanmacı olmayan bir kimlik anlayışının yerleştirilmesiyle, küresel aidiyet duygusunun insanlara kazandırılmasıyla mümkün olabileceğine inanan Sen, küresel kimliğin insanların sahip oldukları yerel ya da ulusal kimliklerle yan yana var olabileceğini öne sürer. Sen'e göre, küresel kimlik ulusal kimliğe bir tehdit oluşturmak şöyle dursun, daha güvenli ve daha adil bir dünya olanağına kapı aralar. Küresel kimlik düşüncesi birbirinden farklı insanları ve ulusları birbirine bağlayan ortak bir kimlik olarak insan varlığının minyatürleştirilmesine, fakirleştirilmesine, çatışma ve şiddeti doğallaştırıp hoşgörüyle bakılmasına karşı durmaya tüm insanları çağırır. Bu çağrı, tüm insanların ortak etik değerlerin ve küresel aidiyet duygusunun çatısı altında birleşmelerine yöneliktir. Böyle bir birleşme, insanları küresel düzeydeki sorunlara yönelik ortak bir tavır almaya yönelterek insanlar arasında nefret tohumları ekilmesinin, şiddeti besleyip kışkırtan kutuplaştırılmış bir vizyonun yayılıp palazlanmasının önünü keser.

$\mathrm{Bu}$ kapsamda sivil toplumun, kamuoyunun akla dayalı sesinin küresel kimlik düşüncesinde önemli bir rol oynayacağını düşünen Sen (2010: 17), küresel kimlik düşüncesinin hayata geçirilmesinde, aralarında Birleşmiş Milletlerin de yer aldığ 1 çok sayıda kurumun, sivil toplum kuruluşlarının, vatandaş örgütlenmelerinin ve haber medyasının bağımsız unsurlarının çabalarının küresel kimlik uygulamasına çağrılmasını talep eder (Durğun, 2013: 117-118). Sen'in bu talebi, tüm insanların barıș ve refahtan adil bir şekilde pay alamadığı, çatışma, şiddet ve özel çıkarlar çerçevesinde şekillenen günümüz dünyasında hiç şüphesiz çok önemlidir. Zira, Sen'in savunduğu küresel kimlik düşüncesi bireylerin, grupların ve toplumların barış ve dayanışma içinde bir arada yaşama imkânına, günümüz dünyasında var olan adaletsizliklere karşı ortak bir insani tavır sergilenmesine ve dolayısıyla daha adil bir dünyanın oluşumuna kapı aralamaktadır.

\section{Kaynakça}

Bauman, Z. (2019). Kimlik. Mesut Hazır (Çev.). 3. Baskı. Ankara: Heretik Yayınları.

Brubaker, R. \& Cooper, F. (2014). “Kimlik”in Ötesine Geçmek. Kübra Kelebekoğlu (Çev.). İçinde: Fırat Mollaer (Ed.), Kimlik Politikaları:Tanınma, Özdeşlik ve Farklılık (ss. 402-460). Ankara: Doğu Batı Yayınları.

Durğun, S. (2013). Amartya Sen: Adalete Küresel Bir Bakış. Ethos: Felsefe ve Toplumsal Bilimlerde Diyaloglar, 6 (1), 95-123.

Foucault, M. (1999). Benlik Teknolojileri. İçinde: G. Çağalı Güven (Çev.), 4. Bask1, Kendini Bilmek (ss.32-85). İstanbul: Om Yayınları.

Gleason, P. (2014). Kimliği Tanımlamak: Semantik Bir Tarih. İçinde: Fırat Mollaer, (Çev.\&Ed.), Kimlik Politikaları:Tanınma, Özdeşlik ve Farklılık (ss. 2152). Ankara: Doğu Batı Yayınları.

Koyuncu, A. A. \& Günerigök, M. (2019). Bauman ve Postmodernite. Konya: Çizgi Kitabevi.

Maalouf, A. (2019). Ölümcül Kimlikler. Aysel Bora (Çev.). 50. Bask1. İstanbul: Yap1 Kredi Yayınları.

Nussbaum, M. C. (2018a). Yapabilirlikler Yaratmak:Insani Gelişmişlik Yaklaşımı. Selda Somuncuoğlu (Çev.). İstanbul: İletişim Yayınları.

Nussbaum, M. C. (2018b). Yeni Dinsel Tahammülsüzlük: Kaygılı Bir Çă̆da Korku Siyasetinin Üstesinden Gelmek. Berkay Ersöz (Çev.). Ankara: Phoenix Yayınevi. 
1293 Durğun, S. / Anemon Muș Alparslan Üniversitesi Sosyal Bilimler Dergisi, 2020 8(4) 1287-1292

Parekh, B. (2014). Kimliğin Mantığı. Suat Aksoy (Çev.). İçinde: Firat Mollaer (Ed.), Kimlik Politikaları:Tanınma, Özdeşlik ve Farklılık (ss. 5378). Ankara: Doğu Batı Yayınları.

Platon (1962). Alkibiades I'den Seçmeler: "Kendini Bilmek, Ruhunu Bilmektir...”. İrfan Şahinbaş (Çev.). İstanbul: Milli Eğitim Basımevi. (Erişim: 15.04.2020), https://vdocuments.site/platonalkibiades.html

Sen, A. (2010). Kimlik ve Siddet.. Ahmet Kardam (Çev.). İstanbul: Optimist Yayınları.
Sen, A. (2009) The Idea Of Justice, CambridgeMassachusetts: The Belknap Press of Harward University Press.

Sen, A. (2004). Özgürlükle Kalkınma. Yavuz Alogan (Çev.). İstanbul: Ayrıntı Yayınları.

Sen, A. (2002). Response to Commentaries. Studies in Comparative International Development, 37, 78-86.

Smith, A. D. (1994). Milli Kimlik. Bahadır Sina Şener (Çev.). İstanbul: İletişim Yayınları.

Tilak, J. B. (2002). Education and Poverty. Journal of Human Development, 3, 191-207. 